\title{
Performance Evaluation of Reverse Osmosis Desalination Pilot Plants using ROSA Simulation Software
}

\author{
Kok Pol Chee ${ }^{1}$, Kok Poh Wai ${ }^{1}$, Chai Hoon $\mathrm{Koo}^{1 *}$, Woon Chan Chong ${ }^{1}$ \\ ${ }^{1}$ Lee Kong Chian Faculty of Engineering and Science, Universiti Tunku Abdul Rahman, Jalan Sungai \\ Long, 43000 Kajang, Selangor, Malaysia.
}

\begin{abstract}
Desalination allows the use of non-conventional water sources such as seawater for the production of potable water. The performance of three pilot plants in Mallard Slough, namely RO1, RO2 and NF3 were investigated. Reverse Osmosis System Analysis (ROSA), a simulation software was adopted for verifying the performance of the existing pilot plants in treating seawater. By inserting the specific system configuration and selecting the membrane specification of the pilot plants, ROSA would help to generate the operating parameters such as feed pressure, flux, recovery ratio, permeate quality of the plants. These results were subsequently being used to compare with the experimental data of the pilot plants to determine their absolute deviations. It was found that all ROSA simulated feed pressures for RO1, RO2 and NF3 fell in the range of operational feed pressures of the existing pilot plants. Besides, the deviation of total dissolved solutes removal between the results simulated by the ROSA software and the results obtained from the experiments were noticeably insignificant. In terms of flux and recovery ratio, the simulated results and the experimental data showed a marginal discrepancy with deviations $<2 \%$ and $<8 \%$ for RO1 and NF3, respectively. In conclusion, the findings of this study confirmed the feasibility of adopting this ROSA software to verify the performance of a pilot plant with all operational parameters being ideally optimized.
\end{abstract}

\section{Introduction}

Water scarcity is one of the top ten problems that human would face in the $21^{\text {st }}$ century [1]. Due to insufficient water resources, desalination plants were built for water softening, aimed to develop a sustainable supply of freshwater for mankind [2]. Membrane desalination has been accepted as an effective and environmental friendly method as compared to thermal desalination [3]. Among others, Reverse Osmosis (RO) membrane with smaller pore size can reject organic compounds and salts up to $99 \%[4,5]$. In facts, RO membrane has been adopted for producing potable water from surface water sources. Five NEWater plants in Singapore are currently using RO membrane to upgrade the

\footnotetext{
* Corresponding author: kooch@utar.edu.my
} 
effluent of sewage treatment plant to indirect potable usage, supplying $40 \%$ of Singapore current water needs.

RO membrane is typically having the pore size of $0.3-0.5 \mathrm{~nm}$ [6] and molecular weight cut off (MWCO) in the range of 150 to $400 \mathrm{Da}$ [7]. Owing to small pore sizes, high membrane pressure is required for RO system. RO membrane is susceptible to fouling without proper treatment, which further increases the operation cost [3]. Nanofiltration (NF) membranes are one of the alternatives to RO membrane since their rejection performance falls between RO and ultrafiltration (UF). The MWCO of NF membrane varies from 200 to $2000 \mathrm{Da}$ [3] while pore size ranged from 1 to $100 \mathrm{~nm}$ [6]. NF possesses lower rejection in monovalent salts, however, requires lower pressure and operation cost. By removing of viruses, bacteria and toxic metal ions from feed, the discharge from NF membrane can be directly used for landscaping, agricultural, pharmaceutical and food industry [8].

Salt rejection in RO is important in order to evaluate the average performances of the overall RO system instead of the performances of individual membrane. This is rather critical in a desalination plant where upgrading seawater to multipurpose fresh water requires high rejection of ions. A well-designed RO system has a very high percentage of salt rejection $(>99 \%)$ to ensure undesired compounds and ions were removed. In some RO system, two-stage membrane (or double passes) configuration is adopted for better solute rejection. A similar design was employed by researchers who successfully desalt seawater to potable quality using two-stage NF treatment process [3].

Flux is expressed as the rate of water permeates into RO membrane in terms of volume per unit area per unit of time. The lesser the number of RO elements in the system, the greater the permeate flow rate and hence the higher the flux ratio. Recovery ratio is the ratio of permeate flow rate to feed flow rate. With a higher recovery ratio, less concentrate is produced and hence the permeate flow rate would be increased. Thus, recovery ratio is strongly dependent on permeate flow rate, which is a function of feed pressure. Higher recovery ratio in $\mathrm{RO}$ system might not associate with better performance, especially when the scaling and fouling issues are much more significant.

In this paper, Reverse Osmosis System Analysis (ROSA) simulation programme was adopted to verify the performance of existing RO and NF membrane pilot plants. The effect of feed pressure, permeate flux, recovery ratio, membrane types and system configuration were taken into account. Results from different pilot plants (RO1, RO2 and NF3) were compared in order to estimate the cost-effectiveness of the process.

\section{Case studies}

\subsection{Plant description}

Three desalination membrane trains were investigated in this study, i.e., RO1, RO2 and NF3. RO system No. 1 (RO1) was an 2:1 array system, combining a series of brackish water membranes (BW30-4040) and seawater membranes (SW30HRLE-4040) in the first and second stage, respectively. Seven elements of membranes were adopted in each vessel for both stages. The reason of BW30-4040 membrans were chosen in first stage is attributed to the desired feedwater quality as well as producing high recovery rate. Meanwhile, seawater membranes (SW30HRLE-4040) were employed in second stage for better salt rejection performance. In fact, these seawater membranes were not installed in first stage because they could not ensure sufficient permeate produced due to their tight membrane structure [3]. 
Meanwhile, RO system No. 2 (RO2) was a single stage treatment system with six elements of SW30HRLE-4040 seawater membrane being configured in each vessel. SW30HRLE-4040 membrane is rather suitable for the RO2 system since the feedwater salinity is the highest among other pilot plants. The NF system No. 3 (NF3) was a single stage NF system with six elements of NF90-4040 membranes being installed in each vessel. Nanofiltration membranes are particularly suitable for the feedwater with lower salinity.

\subsection{Membrane characteristic}

The membrane specifications and operation conditions of RO1, RO2 and NF3 aretabulated in Table 1. All membrane specification was reported at $25^{\circ} \mathrm{C}$ of operation temperature. The BW30-4040 membrane is able to achieve $99.5 \%$ of salt rejection with $15 \%$ of permeate recovery when $\mathrm{NaCl}$ concentration is less than $2000 \mathrm{ppm}$. With a higher operating pressure, SW30HRLE-4040 shows $8 \%$ of permeate recovery and $99.8 \%$ of salt rejection provided that $\mathrm{NaCl}$ concentration is less than $32000 \mathrm{ppm}$. In contrast, the NF90$4040 \mathrm{NF}$ membrane can only reject up to $97 \%$ of $\mathrm{MgSO}_{4}$ when the salt concentration is less than $2000 \mathrm{ppm}$. The recovery ratio of $15 \%$ was achieved under operation pressure of $70 \mathrm{psig}$, which is much lower compared to those for RO membranes. In this study, the simulation results from NF90-4040 membrane were used as a baseline for comparison purpose.

Table 1. Membrane characteristic.

\begin{tabular}{|c|c|c|c|}
\hline $\begin{array}{c}\text { Filmtec } \\
\text { Membrane }\end{array}$ & $\begin{array}{c}\text { Area } \\
\left(\mathbf{m}^{2}\right)\end{array}$ & $\begin{array}{c}\text { Salt Rejection } \\
(\%)\end{array}$ & Simulation condition \\
\hline BW30-4040 & 7.2 & $\begin{array}{c}99.5 @ 2000 \\
\text { ppm NaCl }\end{array}$ & $\begin{array}{l}\mathrm{P}=225 \mathrm{psig}, \mathrm{pH} 8 \\
\text { and } 15 \% \text { recovery }\end{array}$ \\
\hline SW30HRLE-4040 & 7.9 & $\begin{array}{c}99.8 @ 32000 \\
\text { ppm NaCl }\end{array}$ & $\begin{array}{c}\mathrm{P}=800 \text { psig, } \mathrm{pH} 8 \\
\text { and } 8 \% \text { recovery }\end{array}$ \\
\hline NF90-4040 & 7.6 & $\begin{array}{l}97.0 @ 2000 \\
\text { ppm } \mathrm{MgSO}_{4}\end{array}$ & $\begin{array}{c}\mathrm{P}=70 \text { psig and } \\
15 \% \text { recovery }\end{array}$ \\
\hline
\end{tabular}

\subsection{Configuration of pilot plant and seawater composition}

To obtain a reliable result, the pilot plant data from RO1, RO2 and NF3 were extracted based on three operations. The data for Run1 and Run2 were obtained during the dry season whereas Run3 was from wet season. The pilot plant process configurations for $\mathrm{RO} 1, \mathrm{RO} 2$ and NF3 are tabulated in Table 2 for better illustration. Over the past, literature reported that composition of seawater varies throughout the year. The bay area desalination pilot plant report that released by MWH Global Inc. during June 2010 confirmed the findings [9]. Due to the merging of Sacramento River and Joaquin River at Broad Slough, the desalination treatment facility at Mallard Slough will experience a wide range of salinities. As shown in Table 3, the concentrations of ions in seawater during the dry season are slightly lower compared to the wet season. Critically, TDS in seawater during the dry season is much higher than wet season. Besides, it is interesting to note that $\mathrm{pH}$ of seawater remains at $\mathrm{pH} 7.6$ despite the changes in seawater composition. 
Table 2. Process configuration for RO1, RO2 and NF3.

\begin{tabular}{cccc}
\hline Configuration & RO1 & RO2 & NF3 \\
\hline Stage 1 membrane & BW30-4040 & SW30HRLE-4040 & NF90-4040 \\
Number of vessels & 2 & 1 & 1 \\
Elements per vessel & 7 & 6 & 6 \\
Stage 2 membrane & SW30HRLE-4040 & - & - \\
No. of vessels & 1 & - & - \\
Elements per vessel & 7 & - & - \\
\hline
\end{tabular}

Table 3. The composition of feedwater in Mallard Slough Bay, California [9].

\begin{tabular}{lcc}
\hline \multicolumn{1}{c}{ Parameters } & \multicolumn{2}{c}{ Concentration $(\mathbf{m g} / \mathbf{L})$} \\
& Dry Season & Wet Season \\
\hline Total Alkalinity as $\mathrm{CaCO}_{3}$ & 99.3 & 85.6 \\
Total Hardness as $\mathrm{CaCO}_{3}$ & 1109 & 164 \\
Bicarbonate Alkalinity & 99.5 & 85.6 \\
Carbonate Alkalinity & 8.5 & 1.0 \\
Total Calcium $(\mathrm{Ca})$ & 56.5 & 15.0 \\
Total Magnesium $(\mathrm{Mg})$ & 235 & 30.7 \\
Total Potassium $(\mathrm{K})$ & 71.6 & 9.1 \\
Total Sodium $(\mathrm{Na})$ & 1944 & 198 \\
Sulfate $\left(\mathrm{SO}_{4}\right)$ & 458 & 52.3 \\
Barium $(\mathrm{Ba})$ & 0.0485 & 0.0315 \\
Boron $(\mathrm{B})$ & 0.986 & 0.201 \\
Chloride & 3259 & 311 \\
Fluoride & 0.66 & 0.11 \\
Silica & 18.2 & 36.1 \\
TDS & 6339.72 & 740.16 \\
\hline
\end{tabular}

\subsection{Results verification method}

The absolute deviation of the ROSA simulated results from the experimental data can be calculated using Eq. 1.

$$
\text { Deviation }=\frac{\left|i_{\text {exp }}-i_{\text {sim }}\right|}{\left|i_{\text {exp }}\right|} \times 100 \%
$$

where $i_{\text {exp }}$ is the experimental data from pilot plant and $i_{\text {sim }}$ is the ROSA simulated value [11].

\section{ROSA simulated results and pilot plant data}

\subsection{Permeate quality of pilot plats simuated by ROSA software}

The ROSA simulated results for RO1, RO2 and NF3 are presented in Table 4, 5 and 6, respectively. BW30-4040 brackish water membrane that used in RO1 stage 1 operation was aimed to produce pretreated feed for RO1 stage 2-SW30HRLE-4040. During the desalinatin process, concentrates discharged by RO1 stage 1-BW30-4040 membrane would enter RO1 stage 2-SW30HRLE-4040 as feed. This explained why the feed TDS in RO1 is 
doubled compared to those in single stage RO2. From Table 4 and 5, SW30HRLE-4040 in RO1 stage 2 and RO2 desalination plants exhibited a very significant salt rejection which are as close as $100 \%$, regardless of the operating season. However, the permeate quality shown in Table 4 and 5 clearly differentiated that RO1 has higher TDS value than that of RO2 even though same membrane elements (i.e., SW30HRLE-4040) were adopted. This is due to higher feed flow of RO1 comparing to RO2 and NF3 as mentioned earlier [10]. On the contrary, the NF3 simulated by ROSA exhibited relatively low TDS rejection $(\approx$ $88.79 \%$ ) as shown in Table 6 due to lesser salt rejection of NF was applied.

Table 4. Permeate quality of RO1 pilot plant simulated by ROSA software.

\begin{tabular}{|c|c|c|c|c|c|c|c|c|}
\hline \multirow{3}{*}{ Ions } & \multicolumn{5}{|c|}{ Dry Season } & \multicolumn{3}{|c|}{ Wet Season } \\
\hline & \multirow[b]{2}{*}{$\begin{array}{c}\text { Feed } \\
(\mathrm{mg} / \mathrm{L})\end{array}$} & \multicolumn{2}{|c|}{ Run1 } & \multicolumn{2}{|c|}{ Run2 } & \multicolumn{3}{|c|}{ Run3 } \\
\hline & & $\begin{array}{c}\text { Permeate } \\
(\mathrm{mg} / \mathrm{L})\end{array}$ & $\begin{array}{c}\text { Rejection } \\
(\%)\end{array}$ & $\begin{array}{c}\text { Permeate } \\
(\mathrm{mg} / \mathrm{L})\end{array}$ & $\begin{array}{c}\text { Rejection } \\
(\%)\end{array}$ & $\begin{array}{c}\text { Feed } \\
(\mathrm{mg} / \mathrm{L})\end{array}$ & $\begin{array}{c}\text { Permeate } \\
(\mathrm{mg} / \mathrm{L})\end{array}$ & $\begin{array}{c}\text { Rejection } \\
(\%)\end{array}$ \\
\hline $\mathrm{K}$ & 163.48 & 1.23 & 99.25 & 1.32 & 99.19 & 21.99 & 0.14 & 99.36 \\
\hline $\mathrm{Na}$ & 4441.35 & 30.72 & 99.31 & 33.08 & 99.26 & 479.29 & 2.46 & 99.49 \\
\hline $\mathrm{Mg}$ & 539.44 & 1.65 & 99.69 & 1.78 & 99.67 & 74.57 & 0.17 & 99.77 \\
\hline $\mathrm{Ca}$ & 129.71 & 0.39 & 99.70 & 0.42 & 99.68 & 36.44 & 0.08 & 99.78 \\
\hline $\mathrm{CO}_{3}$ & 4.59 & 0.00 & 100.00 & 0.00 & 100.00 & 1.73 & 0.00 & 100.00 \\
\hline $\mathrm{HCO}_{3}$ & 222.04 & 1.92 & 99.14 & 2.07 & 99.07 & 205.00 & 1.27 & 99.38 \\
\hline $\mathrm{Cl}$ & 7884.45 & 51.16 & 99.35 & 55.09 & 99.30 & 824.85 & 3.71 & 99.55 \\
\hline TDS & 14490.35 & 92.95 & 99.36 & 99.95 & 99.31 & 1862.00 & 9.42 & 99.49 \\
\hline $\mathrm{pH}$ & 7.65 & 6.02 & 21.31 & 6.03 & 21.18 & 7.84 & 5.84 & 25.51 \\
\hline
\end{tabular}

Table 5. Permeate quality of RO2 pilot plant simulated by ROSA software.

\begin{tabular}{|c|c|c|c|c|c|c|c|c|}
\hline \multirow{3}{*}{ Ions } & \multicolumn{5}{|c|}{ Dry Season } & \multicolumn{3}{|c|}{ Wet Season } \\
\hline & \multirow[b]{2}{*}{$\begin{array}{c}\text { Feed } \\
(\mathrm{mg} / \mathrm{L})\end{array}$} & \multicolumn{2}{|c|}{ Run1 } & \multicolumn{2}{|c|}{ Run2 } & \multicolumn{3}{|c|}{ Run3 } \\
\hline & & $\begin{array}{c}\text { Permeate } \\
(\mathrm{mg} / \mathrm{L})\end{array}$ & $\begin{array}{c}\text { Rejection } \\
(\%)\end{array}$ & $\begin{array}{c}\text { Permeate } \\
(\mathrm{mg} / \mathrm{L})\end{array}$ & $\begin{array}{c}\text { Rejection } \\
(\%)\end{array}$ & $\begin{array}{c}\text { Feed } \\
(\mathrm{mg} / \mathrm{L})\end{array}$ & $\begin{array}{c}\text { Permeate } \\
(\mathrm{mg} / \mathrm{L})\end{array}$ & $\begin{array}{c}\text { Rejection } \\
(\%)\end{array}$ \\
\hline $\mathrm{K}$ & 71.60 & 0.38 & 99.47 & 0.37 & 99.48 & 9.10 & 0.05 & 99.45 \\
\hline $\mathrm{Na}$ & 1944.00 & 8.70 & 99.55 & 8.61 & 99.56 & 198.00 & 0.89 & 99.55 \\
\hline $\mathrm{Mg}$ & 235.00 & 0.25 & 99.89 & 0.25 & 99.89 & 30.70 & 0.04 & 99.87 \\
\hline $\mathrm{Ca}$ & 56.50 & 0.06 & 99.89 & 0.06 & 99.89 & 15.00 & 0.02 & 99.87 \\
\hline $\mathrm{CO}_{3}$ & 0.78 & 0.00 & 100.00 & 0.00 & 100.00 & 0.30 & 0.00 & 100.00 \\
\hline $\mathrm{HCO}_{3}$ & 99.50 & 0.70 & 99.30 & 0.70 & 99.30 & 85.60 & 0.61 & 99.29 \\
\hline $\mathrm{Cl}$ & 3449.45 & 14.09 & 99.59 & 13.95 & 99.60 & 311.00 & 1.29 & 99.59 \\
\hline TDS & 6339.72 & 25.47 & 99.60 & 25.24 & 99.60 & 740.16 & 3.46 & 99.53 \\
\hline $\mathrm{pH}$ & 7.60 & 5.69 & 25.13 & 5.67 & 25.39 & 7.60 & 5.58 & 26.58 \\
\hline
\end{tabular}


Table 6. Permeate quality of NF3 pilot plant simulated by ROSA software.

\begin{tabular}{|c|c|c|c|c|c|c|c|c|}
\hline \multirow{3}{*}{ Ions } & \multicolumn{5}{|c|}{ Dry Season } & \multicolumn{3}{|c|}{ Wet Season } \\
\hline & \multirow{2}{*}{$\begin{array}{c}\text { Feed } \\
(\mathrm{mg} / \mathrm{L})\end{array}$} & \multicolumn{2}{|c|}{ Run1 } & \multicolumn{2}{|c|}{ Run2 } & \multicolumn{3}{|c|}{ Run3 } \\
\hline & & $\begin{array}{c}\text { Permeate } \\
(\mathrm{mg} / \mathrm{L})\end{array}$ & $\begin{array}{c}\text { Rejection } \\
(\%)\end{array}$ & $\begin{array}{c}\text { Permeate } \\
(\mathrm{mg} / \mathrm{L})\end{array}$ & $\begin{array}{c}\text { Rejection } \\
(\%)\end{array}$ & $\begin{array}{c}\text { Feed } \\
(\mathrm{mg} / \mathrm{L})\end{array}$ & $\begin{array}{c}\text { Permeate } \\
(\mathrm{mg} / \mathrm{L})\end{array}$ & $\begin{array}{c}\text { Rejection } \\
(\%)\end{array}$ \\
\hline $\mathrm{K}$ & 71.60 & 6.20 & 91.34 & 9.84 & 86.26 & 9.10 & 0.93 & 89.78 \\
\hline $\mathrm{Na}$ & 1944.00 & 158.33 & 91.86 & 252.53 & 87.01 & 198.00 & 17.70 & 91.06 \\
\hline $\mathrm{Mg}$ & 235.00 & 5.83 & 97.52 & 9.61 & 95.91 & 30.70 & 0.91 & 97.04 \\
\hline $\mathrm{Ca}$ & 56.50 & 1.37 & 97.58 & 2.27 & 95.98 & 15.00 & 0.44 & 97.07 \\
\hline $\mathrm{CO}_{3}$ & 0.78 & 0.00 & 100.00 & 0.00 & 100.00 & 0.30 & 0.00 & 100.00 \\
\hline $\mathrm{HCO}_{3}$ & 99.50 & 3.44 & 96.54 & 5.62 & 94.35 & 85.60 & 3.25 & 96.20 \\
\hline $\mathrm{Cl}$ & 3449.45 & 262.94 & 92.38 & 420.04 & 87.82 & 311.00 & 29.03 & 90.67 \\
\hline TDS & 6339.72 & 444.75 & 92.98 & 710.81 & 88.79 & 740.16 & 55.00 & 92.57 \\
\hline $\mathrm{pH}$ & 7.60 & 6.29 & 17.24 & 6.47 & 14.87 & 7.60 & 6.26 & 17.63 \\
\hline
\end{tabular}

\subsection{Comparison of ROSA simulated results with pilot plant experimental data}

Table 7 compares the permeate parameters between the ROSA simulated results and experimental data obtained on $28^{\text {th }}$ January 2009 for RO2 Run2. The absolute deviation values of each parameter are also presented in Table 7. It was found that the permeate quality of pilot plant data was significantly deviated from those simulated in ROSA software. This could be attributed to antiscalant option was not considered in the software due to unavailability of informtion from the engineering report. The assumption of not considering antiscalant in the simulation might give rise to this error. Besides, there might be some variation in feed salinity due to merging of Sacramento River and Joaquin River at Broad Slough, a joining near to Mallard Slough. However, the deviations between the ROSA simulated software and RO2 pilot plant Run2 data for pH and TDS are marginally, i.e., $1.56 \%$ and $5.17 \%$, respectively. This has proven that SW30HRLE-4040 membrane in RO2 pilot plant was working efficiently in removing TDS from the seawater due to all the permeate quality are in compliance with Drinking Water Quality Standards (DWQS).

Feed pressure, flux and recovery between the ROSA simulated results and pilot plant data for RO1, RO2 and NF3 are presented in Table 8. All experimental data fell in the range of ROSA simulated values. The ROSA simulated feed pressure was 250 psi which was within the range of pilot plant experimental data (i.e., 230 to $320 \mathrm{psi}$ ). This has implied that both results did not much deviation between each other. A similar trend was observed in Run2 and Run3, as well as the operation in RO2 and NF3. On top of that, both pilot plant experiment data and ROSA simulated results have proven that increasing feed pressure would improve the flux as well as the recovery. The operating pressure for Run 3 is always lower than those in Run1 and Run2 owing to a lower solute concentration during the wet season. Even though higher operating feed pressure will increase flux, however, this would increase the specific energy required and thus increase the operation cost [3]. Besides, RO system operates at high pressure would easily cause the membrane to foul or fracture [12]. The ROSA simulated results show that the feed pressure and a number of stages are the two most important parameters that have a great influence on the performance of the membranes. 
Table 7. Comparison of permeate parameters between the ROSA simulated results and pilot plant data for RO2 Run2.

\begin{tabular}{|c|c|c|c|c|}
\hline $\begin{array}{l}\text { Permeate } \\
\text { Parameters }\end{array}$ & $\begin{array}{c}\text { ROSA } \\
\text { Simulation } \\
\text { Values }\end{array}$ & $\begin{array}{c}\text { Pilot Plant } \\
\text { Experimental } \\
\text { Data }\end{array}$ & $\begin{array}{c}\text { Absolute } \\
\text { Deviation } \\
(\%)\end{array}$ & DWQS \\
\hline $\begin{array}{l}\text { Total alkalinity } \\
\mathrm{CaCO}_{3}(\mathrm{mg} / \mathrm{L})\end{array}$ & 0.57 & 1.2 & 52.50 & - \\
\hline $\begin{array}{l}\text { Total hardness as } \\
\mathrm{CaCO}_{3}(\mathrm{mg} / \mathrm{L})\end{array}$ & 1.2 & 2.9 & 58.62 & 500 \\
\hline $\begin{array}{l}\text { Calcium hardness as } \\
\mathrm{CaCO}_{3}(\mathrm{mg} / \mathrm{L})\end{array}$ & 0.1 & 1.6 & 93.75 & - \\
\hline $\begin{array}{l}\text { Carbon dioxide as } \\
\mathrm{CO}_{2}(\mathrm{mg} / \mathrm{L})\end{array}$ & 2.35 & 17 & 86.18 & - \\
\hline Sulfate $(\mathrm{mg} / \mathrm{L})$ & 0.19 & 1.1 & 82.73 & 250 \\
\hline Chloride $(\mathrm{mg} / \mathrm{L})$ & 13.95 & 27 & 48.33 & 250 \\
\hline TDS (mg/L) & 25.24 & 24 & 5.17 & 1000 \\
\hline $\mathrm{pH}$ & 5.67 & 5.76 & 1.56 & $6.5-9$ \\
\hline
\end{tabular}

Table 8. Comparison of feed pressure, flux and recovery between the ROSA simulated results and pilot plant data for RO1, RO2 and NF3.

\begin{tabular}{|c|c|c|c|c|c|c|c|c|c|}
\hline \multirow[b]{2}{*}{ Plant } & \multirow[b]{2}{*}{ Run } & \multicolumn{2}{|c|}{$\begin{array}{c}\text { Feed Pressure } \\
\text { (psi) }\end{array}$} & \multicolumn{3}{|c|}{ Flux (gfd) } & \multicolumn{3}{|c|}{ Recovery (\%) } \\
\hline & & $\begin{array}{c}\text { ROSA } \\
\text { Simulated } \\
\text { Result }\end{array}$ & $\begin{array}{l}\text { Pilot } \\
\text { Plant } \\
\text { Result }\end{array}$ & $\begin{array}{c}\text { ROSA } \\
\text { Simulatec } \\
\text { Result }\end{array}$ & $\begin{array}{l}\text { Pilot } \\
\text { d Plant } \\
\text { Result }\end{array}$ & $\begin{array}{c}\begin{array}{c}\text { Absolute } \\
\text { deviation } \\
(\%)\end{array} \\
\end{array}$ & $\begin{array}{c}\text { ROSA } \\
\text { Simulate } \\
\text { d Result }\end{array}$ & $\begin{array}{l}\text { Pilot } \\
\text { Plant } \\
\text { Result } \\
\end{array}$ & $\begin{array}{c}\text { Absolute } \\
\text { deviation } \\
(\%)\end{array}$ \\
\hline \multirow{3}{*}{ RO1 } & $\begin{array}{l}\text { Run1 } \\
\left(D^{*}\right)\end{array}$ & 250 & $\begin{array}{c}230- \\
320\end{array}$ & 12.03 & 12.0 & 0.25 & 70.44 & 70 & 0.63 \\
\hline & $\begin{array}{l}\text { Run2 } \\
\left(\mathrm{DS}^{*}\right)\end{array}$ & 260 & $\begin{array}{l}170- \\
270\end{array}$ & 11.99 & 12.0 & 0.08 & 74.01 & 74 & 0.01 \\
\hline & $\begin{array}{l}\text { Run3 } \\
\text { (WS*) }\end{array}$ & 120 & $\begin{array}{l}120- \\
170\end{array}$ & 12.16 & 12.0 & 1.33 & 82.00 & 82 & 0.00 \\
\hline \multirow{3}{*}{$\mathrm{RO} 2$} & $\begin{array}{l}\text { Run1 } \\
\left(\mathrm{DS}^{*}\right)\end{array}$ & 280 & $\begin{array}{l}190- \\
280\end{array}$ & 9.81 & 12.7 & 22.76 & 38.59 & 50 & 22.82 \\
\hline & $\begin{array}{l}\text { Run2 } \\
\left(\mathrm{DS}^{*}\right)\end{array}$ & 320 & $\begin{array}{l}200- \\
320\end{array}$ & 11.32 & 14.1 & 19.72 & 50.12 & 50 & 0.24 \\
\hline & $\begin{array}{l}\text { Run3 } \\
\text { (WS })\end{array}$ & 225 & $\begin{array}{l}175- \\
225\end{array}$ & 11.71 & 14.1 & 16.95 & 55.27 & 62 & 10.85 \\
\hline \multirow{3}{*}{ NF3 } & $\begin{array}{l}\text { Run1 } \\
\left(\mathrm{DS}^{*}\right)\end{array}$ & 165 & $\begin{array}{c}130- \\
190\end{array}$ & 13.08 & 13.2 & 0.91 & 49.67 & 50 & 0.66 \\
\hline & $\begin{array}{l}\text { Run2 } \\
\left(\mathrm{DS}^{*}\right)\end{array}$ & 145 & $\begin{array}{l}110- \\
160\end{array}$ & 11.88 & 12.9 & 7.91 & 50.75 & 55 & 7.73 \\
\hline & $\begin{array}{l}\text { Run3 } \\
\left.\text { (WS }{ }^{*}\right)\end{array}$ & 12.92 & 12.90 & 12.92 & 12.9 & 0.16 & 58.85 & 60 & 1.92 \\
\hline
\end{tabular}

${ }^{*} \mathrm{DS}=$ Dry season, $\mathrm{WS}=$ Wet season

In terms of flux, the deviations are reasonably within the range, which is less than $10 \%$ for RO1 and NF3. The discrepancies between experimental data and the ROSA simulated results in RO1 Run 2 were $0.08 \%$ for flux. This shows that the pilot plant was working 
efficiently and performed ideally as per design. For NF3, the deviation of $7.91 \%$ in flux was deemed tolerable and this has confirmed the accuracy and reliability of the ROSA simulation software. In contrast, a significant deviation in flux between the ROSA simulated results and pilot plant data was observed in RO2 Run1. However, the deviation was found decreasing gradually when the feed pressure was decreased as observed in Run2 and Run3. The deviation might due to incomplete data input in which the antiscalant used in the pilot plant is not being considered in the ROSA software as mentioned earlier. In terms of recovery, Run 2 shows only $0.24 \%$ of discrepancy between the ROSA simulated results and experimental data in $\mathrm{RO} 2$. It was found that the simulated recovery rate was $50.12 \%$ while the pilot plant was running at $50 \%$ recovery.

RO1 with double pass configuration show higher recovery ratio than single stage RO2 even though identical membrane elements were adopted in both systems. Higher recovery produces larger amount of permeate by recycling lesser concentrates to stage 1 feed [13]. However, this does not guarantee permeate quality as the recovery rate is inversely proportional to salt rejection rate [12]. A research work carried out by Oh et al. [14] reported that increasing recovery rate would increase the concentration of solute in permeate, as well as the necessary feed pressure. Similar trend was observed in this study in which the permeate TDS in RO2 was lower than that of RO1, as depicted in Table 4 and Table 5, respectively. The recovery rate for each membrane element is the key to control scaling, fouling and polarization problems occur at the membrane surface. It is a common engineering practice to design a brackish RO system such that the average recovery rate per 40 -inch long membrane element will be about 9\% [15]. Nevertheless, the number of concentrate stages in the RO system will depend on the permeate recovery ratio and the number of membrane elements per pressure vessel. The recovery rate per individual membrane element should not exceed $18 \%$ to reduce concentration polarization at the membrane surface. In this study, the recovery rate per membrane element is far below the limit. Besides, the literature reported that water recovery in seawater desalination plants varies from $35-85 \%$ which depends upon the composition and salinity of feed water, pretreatment, and concentrate disposal [5]. From Table 8, the recovery rate determined by ROSA simulation ranged from 38.59 to $82 \%$, whereas the actual recovery rate from the pilot plant was between $50 \%$ and $82 \%$. Hence, both ROSA and pilot plant data were complying with the background theory reported in the literature.

\section{Conclusions}

The desalination performance of three pilot plants (i.e., 2 RO and $1 \mathrm{NF}$ plants) in Mallard Slough, California was being evaluated using ROSA software in this study. By observing the individual plant performance, single stage RO2 system has well-performed and achieved highest salt rejection rate among others. The double pass RO1 system has produced the greatest most volume of permeate and achieved a highest recovery rate of $82 \%$ while RO2 and NF3 were $62 \%$ and $60 \%$, respectively. Through the experimental data, the feed pressure of all three pilot plants fluctuated around the simulated results. In terms of flux and recovery, the experimental data from RO1 and NF3 pilot plant complied with the ROSA simulated results. Slight discrepancies at deviation $<2 \%$ for RO1 and deviation $<8 \%$ for NF3 were observed for flux and recovery ratio. In contrast, the pilot plant data for RO2 was significantly deviated from the ROSA simulated results. This could be attributed to antiscalant option was not considered in the software due to unavailability of information from the engineering report. The assumption of not considering antiscalant in the simulation might give rise to this error. Besides, there might be some variation in feed salinity due to merging of Sacramento River and Joaquin River at Broad Slough, a joining near to Mallard Slough. For $\mathrm{pH}$ and TDS removal, the deviation between ROSA simulation 
and experiment data from RO1, RO2 and NF3 were deemed insignificant. This has confirmed the reliability of using ROSA software to verify pilot plant performance.

The authors wish to express their gratitude to Universiti Tunku Abdul Rahman (UTAR) for providing financial support under vote no. 6251/K02.

\section{References}

1. $\quad$ K.T. Lee, K.P. Wai, S.Y. Lu, J Taiwan Inst Chem Eng. 70, 244-251 (2017)

2. G. Vaseghi, A. Ghassemi, J. Loya, Desalin Water Treat. 57, 23461-23472 (2016)

3. A. AlTaee, A.O. Sharif, Desalination. 273, 391-397 (2011)

4. T. Fujioka, K.P. Ishida, T. Shintani, H. Kodamatani, Water Res. 131, 45-51 (2017)

5. A. Anand, B. Unnikrishnan, J.-Y. Mao, H.-J. Lin, C.-C. Huang, Desalination. 429, 119-133 (2018)

6. B.S. Lalia, V. Kochkodan, R. Hashaikeh, N. Hilal, Desalination. 326, 77-95 (2013)

7. P. Krzeminski, C. Schwermer, A. Wennberg, K. Langford, C. Vogelsang, J Hazard Mater. 323, 166-176 (2017)

8. A.W. Mohammad, Y.H. Teow, W.L. Ang, Y.T. Chung, D.L. Oatley-Radcliffe, N. Hilal, Desalination. 356, 226-254 (2015)

9. C. Bromley, Pilot Testing at Mallard Slough Pilot Plant Engineering Report, MWH Global Inc.: California. 4-7 (2010)

10. M.A. Mustaqimah, M. Alghoul, P. Poovanaesvaran, A.M.F.F. Annisa, K. Sopian, Comparison of One Stage and Two Stage-Brackish Water Reverse Osmosis System: A Simulation study, in Computational Methods in Science and Engineering (2013)

11. F. Rezazadeh, W.F. Gale, M. Akram, K.J. Hughes, M. Pourkashanian, International Journal of Greenhouse Gas Control. 53, 243-253 (2016)

12. Arvind Patil, Gary Hatch, Charles Michaud, Mark Brotman, P. Regunathan, R. Tallon Basics of Spiral wound RO Membranes. 4 (2013)

13. Lanxess, Principles of Reverse Osmosis Membrane Separation, Lanxess Deutschland GmbH: Cologne (2013)

14. H.-J. Oh, T.-M. Hwang, S. Lee, Desalination. 238, 128-139 (2009)

15. Hydranautics, High Performance Membrane Products, Nitto Denko Corp: Osaka, Japan (2001) 